\title{
Hypothalamic regulation of food intake and clinical therapeutic applications
}

\author{
Regulação hipotalâmica da ingestão alimentar \\ e suas aplicações terapêuticas clínicas
}

Katherine Anne Simpson', Niamh M. Martin', Stephen R. Bloom'

${ }^{1}$ Department of Investigative Medicine, Imperial College, London, United Kingdom
Correspondence to: Stephen R. Bloom Department of Investigative Medicine, Imperial College London W12 ONN, UK s.bloom@imperial.ac.uk

Received in Feb/03/2009 Accepted in Feb/15/2009

\begin{abstract}
Current estimates suggest that over 1 billion people are overweight and over 300 million people are obese. Weight gain is due to an imbalance between energy expenditure and dietary intake. This review discusses the hypothalamic control of appetite and highlights key developments in research that have furthered our understanding of the complex pathways involved. Nuclei within the hypothalamus integrate peripheral signals such as adiposity and caloric intake to regulate important pathways within the central nervous system controlling food intake and energy expenditure. Firmly established pathways involve the orexigenic NPY/AgRP and the anorexigenic POMC/CART neurons in the arcuate nucleus (ARC) of the hypothalamus. These project from the ARC to other important hypothalamic nuclei, including the paraventricular, dorsomedial, ventromedial and lateral hypothalamic nuclei. In addition there are many projections to and from the brainstem, cortical areas and reward pathways, which modulate food intake. Arq Bras Endocrinol Metab. 2009;53(2):120-128.

Keywords

Hypothalamus; obesity; appetite; arcuate nucleus; orlistat; sibutramine
\end{abstract}

\section{RESUMO}

As estimativas atuais sugerem que mais de 1 bilhão de pessoas apresentam sobrepeso e 300 milhões são obesas. 0 ganho de peso representa um desequilíbrio entre o gasto energético e o consumo alimentar. Esta revisão discute o controle hipotalâmico do apetite e destaca os pontos-chave no desenvolvimento de pesquisas para ampliar o nosso entendimento dos complexos mecanismos envolvidos nesta regulação. Núcleos situados no hipotálamo integram uma série de sinais com o sistema nervoso central controlando a ingestão alimentar e o gasto energético. As vias mais estabelecidas envolvem os neurônios orexigênicos NPY/AgRP e os neurônios anorexigênicos POMC/CART no núcleo arqueado (ARC) do hipotálamo. Esses neurônios se projetam do ARC para outros importantes núcleos hipotalâmicos, tais quais: paraventricular, dorsomedial, ventromedial e lateral. Além disso, existem várias projeções que vão e vem do tronco cerebral, das áreas corticais e das vias de retroalimentação que modulam o consumo alimentar. Arq Bras Endocrinol Metab. 2009;53(2):120-128.

Descritores

Hipolátamo; obesidade; apetite; núcleo arqueado; orlistate, sibutramina

\section{INTRODUCTION}

C Turrent estimates suggest that over 1 billion people are overweight and over 300 million people are obese (1). Furthermore, $80 \%$ of obese adults have at least one or more co-morbidities including diabetes mellitus, hyperlipidaemia, hypertension, cardiovascular disease and have a significant increase in many forms of cancer (2). The increasing prevalence of obesity is partly attrib- utable to a lack of exercise and partly to the availability of high calorie palatable food. In addition family, twin and adoption studies indicate that obesity is highly heritable, with the estimated genetic contribution ranging from $60-84 \%$ (3). The concept of a "thrifty phenotype" was contemplated in the 1950s and suggested that carriers of genes that enabled storage of energy more efficiently during periods of abundant food supply increased their 
odds of survival during famine. However this "thrifty genotype" becomes a disadvantage at times of abundant energy supply, resulting in obesity. A series of complex systems maintain energy homeostasis in order that sufficient energy is available and body weight remains stable. Central circuits in the brain rely on peripheral signals indicating satiety levels and energy stores, as well as higher cortical factors such as emotional and reward pathways. As illustrated in Figure 1, the hypothalamus is critical in the relaying of afferent signals from the gut and brainstem as well as processing efferent signals that modulate food intake and energy expenditure. The hypothalamus is subdivided into interconnecting nuclei, including the arcuate nucleus (ARC), paraventricular nucleus (PVN), ventromedial nucleus (VMN), dorsomedial nucleus $(\mathrm{DMN})$ and lateral hypothalamic area (LHA). Neuronal pathways between these nuclei are organised into a complex network in which orexigenic and anorexigenic circuits influence food intake and energy expenditure. The purpose of this review is to provide some clarity of this complex network and its role in appetite, highlighting areas of potential therapeutic targets for obesity.

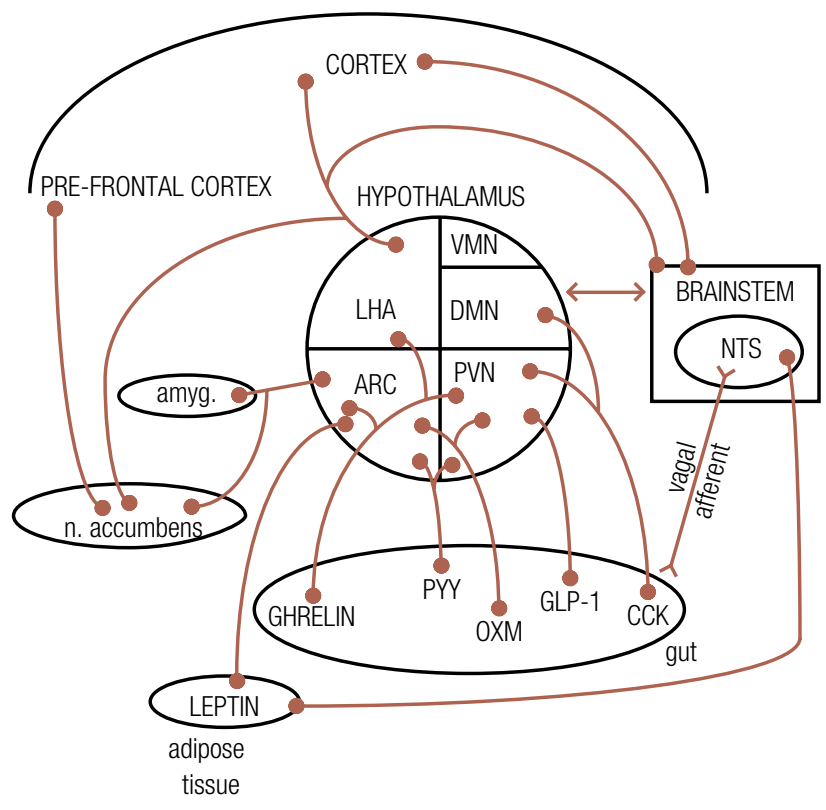

NTS = nucleus tractus solitarius; amyg = amygdala; $n$. accumbens = nucleus accumbens.

Figure 1. Pathways are shown between the brainstem, hypothalamus, cortical areas and reward circuitry known to regulate appetite control. There are also projections from hypothalamic nuclei to the pre-frontal cortex, involved in conditioned taste aversion, as well as reward centres such as the amygdala and nucleus accumbens. Gut hormones acting via vagal afferents act on nuclei within the brainstem which in turn signal to the hypothalamus. Some gut hormones may also act directly on hypothalamic nuclei via the circulation and across an incomplete blood brain barrier. Leptin is also thought to act directly on the brainstem nuclei as well as hypothalamic nuclei suggesting that it can modulate appetite through different pathways.

\section{HYPOTHALAMIC NUCLEI INVOLVED IN APPETITE CONTROL}

\section{Arcuate nucleus (ARC)}

The ARC is a key hypothalamic nucleus in the regulation of appetite. In mice, lesions of the ARC result in obesity and hyperphagia (4). Its proximity to the median eminence and the fact that the ARC is not fully insulated from the circulation by the blood brain barrier means it is strategically positioned to integrate a number of peripheral signals controlling food intake (Figure 2). There are two major neuronal populations in the ARC implicated in the regulation of feeding. One population increases food intake and co-expresses neuropeptide $\mathrm{Y}(\mathrm{NPY})$ and agouti-related protein $(\mathrm{AgRP})$. The second population of neurons co-expresses cocaine- and amphetamine-related transcript (CART) and pro-opiomelanocortin (POMC) and inhibits food intake. Neuronal projections from these two populations then communicate with other hypothalamic areas involved in appetite regulation such as the PVN, DMN and LHA (5).

\section{CART/POMC neurons}

Cleavage of POMC by prohormone convertases $\mathrm{PCl}$ and PC2 produces melanocortins which exert their effects through binding to G-protein coupled melanocortin receptors (MC-Rs). Five melanocortin receptors have been cloned however only the MC3-R and MC4-R are expressed in the brain (6). The MC4-R is highly expressed in the hypothalamus, most notably the PVN (6). Targeted deletion of the MC4-R in mice results in hyperphagia, reduced energy expenditure and obesity, underlying the importance of this receptor in appetite regulation (7). The role of the MC3-R remains less clear however MC3 receptor $(\mathrm{Mc} 3 \mathrm{r})$ knockout mice have a higher fat content and reduced lean body mass (8).

Melanocortin peptides, including $\alpha$-MSH, released from ARC POMC neurons bind to downstream MC4Rs to inhibit food intake (9). Consistent with this, knockout mice lacking all POMC derived peptides display increased food intake and weight gain (10). $\mathrm{AgRP}$ is the endogenous antagonist at the MC3-R and MC4-R (11) suggesting that melanocortinergic neurons may exert a "tonic" inhibition on feeding and permit increased energy expenditure, which is relaxed following AgRP antagonism of the MC3 and MC4Rs, ultimately resulting in stimulation of feeding and a lower metabolic rate. 


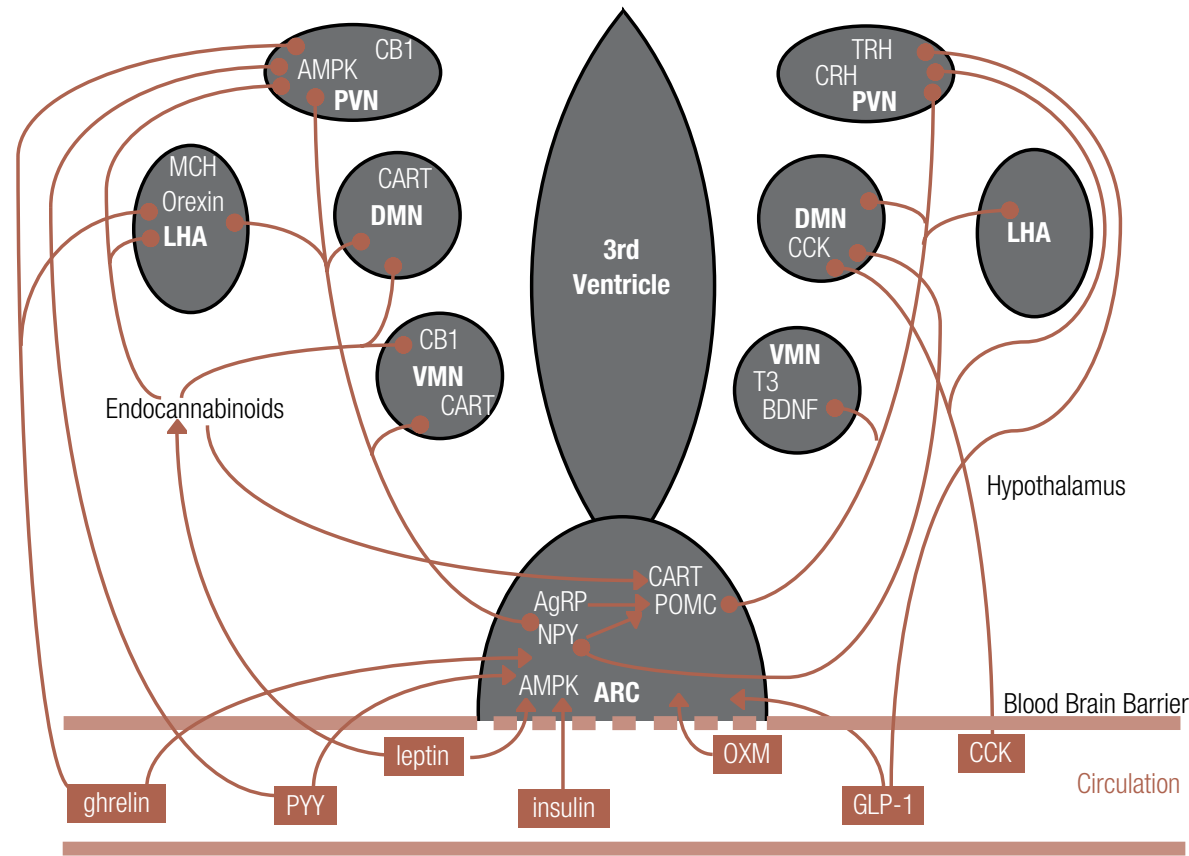

$\mathrm{ARC}=$ arcuate nucleus; $\mathrm{PVN}=$ paraventricular nucleus; VMN = ventromedial nucleus; $\mathrm{DMN}=$ dorsomedial nucleus; $\mathrm{LHA}=$ lateral hypothalamic area; $\mathrm{BDNF}=$ brain-derived neurotrophic factor; CB1= endocannabinoid receptor 1; $\mathrm{MCH}=$ melanin concentrating hormone; $\mathrm{CCK}=$ cholecystokinin; GLP-1 = glucagon-like peptide 1; OXM = oxyntomodulin; PYY = peptide YY; AgRP = agouti related protein; NPY = neuropeptide Y; POMC = pro-opiomelanocortin; CART = cocaine- and amphetamine-related transcript; AMPK = adenosine mono-phosphate protein kinase.

Figure 2. The main hypothalamic nuclei, neuropeptides and pathways involved in the regulation of appetite. Circulating hormones act directly on the ARC affecting downstream pathways which modulate appetite control. In the ARC, orexigenic neurons co-express NPY and AgRP, whereas neurons co-expressing POMC and CART are anorexigenic.

Several recent studies have demonstrated the importance of the melanocortin system in regulating energy homeostasis in humans. MC4R mutations account for approximately $6 \%$ of severe early onset human obesity and as many as 90 different mutations have been associated with obesity (12). Homozygous mutations in the $P O M C$ gene in humans results in early onset obesity, adrenal insufficiency and red hair pigmentation (13).

The majority of POMC neurons in the ARC also co-express CART mRNA. Animal studies have shown that ICV administration of CART inhibits food intake, whereas ICV injection of CART antiserum increases food intake (14). However, preventing CSF flow between the $3^{\text {rd }}$ and $4^{\text {th }}$ ventricles by plugging the cerebral aqueduct abolishes the anorectic effect of CART following its administration into the $3^{\text {rd }}$ ventricle (15). This suggests that the anorectic effects of CART occur through the hindbrain rather than the hypothalamus.

Interestingly, transgenic mice which are CARTdeficient do not demonstrate significant alterations in feeding behaviour or body weight when fed a normal $\operatorname{diet}(16)$. In addition, recent studies have proposed that CART may also have an orexigenic role since CART injected directly into the VMN or ARC of fasted rats causes a significant increase in food intake at 1-2 hours (17). Similarly, twice daily intra-ARC injection of CART for one week in rats results in a $60 \%$ increase in food intake and CART overexpression using a CART transgene construct increases cumulative food intake and weight gain (18). This suggests that there may be distinct neuronal circuits within the hypothalamus in which CART can act as an orexigenic or anorexigenic signal.

\section{NPY/AgRP neurons}

Within the hypothalamus, NPY is an important regulator of body weight through its effects on food intake and energy expenditure. NPY acts at five different receptors (Y1-Y5 receptors), although NPY appears to exert its orexigenic effect predominantly via the $\mathrm{Yl}$ and $\mathrm{Y} 5$ receptors. The majority of neurons expressing NPY in the hypothalamus are found within the ARC and most co-express AgRP $(11,19)$. Ablation of NPY/ $\mathrm{AgRP}$ neurons in young mice reduces food intake and body weight (20) whilst in adult rats, ICV injection of NPY potently stimulates food intake (21). NPY/AgRP 
neurons have extensive projections within the hypothalamus including the PVN, DMN and LHA which appear to be the main targets for the orexigenic effects of NPY $(11,19,22)$. Approximately $20 \%$ of ARC NPY neurons innervate the PVN and DMN (22). Stimulation of this pathway leads to increased food intake through direct stimulation of $\mathrm{Yl}$ and $\mathrm{Y} 5$ receptors in addition to AgRP antagonism of MC3 and MC4-Rs in the PVN.

\section{Paraventricular nucleus (PVN)}

Microinjection of almost all known orexigenic peptides into the PVN, including NPY and AgRP stimulate feeding $(23,24)$. NPY/AgRP neurons from the ARC communicate with PVN neurons containing thyrotrophin releasing hormone (TRH) (25) which has been implicated in the control of energy balance, by contributions to both food intake and energy expenditure (26).

\section{Lateral hypothalamic area (LHA)}

The LHA receives neuronal projections from the ARC and contains the orexigenic neuropeptides melanin concentrating hormone $(\mathrm{MCH})$ and orexins. NPY, AgRP and $\alpha-\mathrm{MSH}$ immunoreactive terminals are extensive in the LHA and are in contact with $\mathrm{MCH}$ and orexinexpressing cells (27). MCH immunoreactive fibres also project to the cortex, brainstem and spinal cord (28).

In humans, two $\mathrm{MCH}$ receptors have been cloned in humans, $M c h r l$ and $M c h r 2$ whereas in rodents only $M c h r l$ has been identified. Mchrl knockout mice have increased energy expenditure, locomotor activity and are resistant to diet-induced obesity (29). In contrast, injection of $\mathrm{MCH}$ into the lateral ventricle of rats increases food intake and fasting increases the expression of Mch mRNA (30). Orexin A and B act via two receptors, OXIR and OX2R and ICV administration of these peptides increases food intake (31). However, subsequent studies have proposed that this may reflect associated heightened arousal and reduced sleep (32).

\section{Dorsomedial nucleus (DMN)}

Destruction of the DMN results in hyperphagia and obesity (33). The DMN contains a high level of NPY terminals (19) and $\alpha-\mathrm{MSH}$ terminals originating in the ARC (34). $\alpha$-MSH fibres also project from the DMN to the PVN terminating on TRH-containing neurons (35). In diet-induced obesity, obese agouti mice and $\mathrm{Mc} 4 \mathrm{r}$ knockout mice, NPY mRNA expression is increased in the DMN $(36,37)$.

\section{Ventromedial nucleus (VMN)}

Neuroimaging studies in humans have shown increased signal in the area of the VMN following an oral glucose load (38). The VMN contains a large population of glucoresponsive neurons and receives NPY, AgRP and POMC neuronal projections from the ARC. Brain-derived neurotrophic factor (BDNF) is highly expressed in the VMN and lateral ventricle administration of BDNF reduces food intake and body weight (39). It is thought that ARC POMC neurons have a role in activating VMN BDNF neurons to decrease food intake (40).

\section{ADIPOSITY SIGNALS ACTING ON THE HYPOTHALAMUS}

Adipokines are secreted by adipose tissue and include leptin, adiponectin and resistin. They have been shown to act via the hypothalamus to affect food intake and energy expenditure (41). Leptin is secreted by adipocytes and circulates at concentrations proportional to fat mass. Rodents lacking leptin ( $o b / o b$ mice) or the leptin receptor ( $d b / d b$ mice and Zucker $f a / f a$ rats) are obese and hyperphagic. In humans, the rare condition of leptin deficiency causes severe obesity which can be ameliorated by peripheral leptin administration (42).

Circulating leptin crosses the blood brain barrier and binds to the long form of the leptin receptor, Ob$\mathrm{Rb}$, in the hypothalamus (43). The Obr receptor is expressed widely within the hypothalamus but particularly in the ARC, VMN, DMN and LHA. Using viral mediated gene expression, chronic leptin over-expression in the ARC, PVN and VMN results in reduced food intake (44). In the ARC, Ob-Rb mRNA is expressed by both NPY/AgRP and CART/POMC neurons. Leptin directly activates anorectic POMC neurons and inhibits orexigenic AgRP/NPY neurons resulting in an overall reduction in food intake (45).

Circulating insulin rises in response to a glucose load and like leptin, circulating levels reflect fat mass. Insulin crosses the blood brain barrier via receptor-mediated transport. Insulin receptors are widely distributed in the brain particularly in hypothalamic nuclei involved in the regulation of food intake. Insulin has an anorectic effect when administered ICV or directly into the VMN, an effect which is reversed by insulin antibodies (46). The 
precise mechanism by which insulin inhibits food intake is still unclear although administration of insulin into the $3^{\text {rd }}$ ventricle of fasted rats increases ARC POMC mRNA expression and reduces food intake (47). This anorexigenic effect of insulin is blocked by melanocortin antagonists (47).

\section{INTERACTIONS BETWEEN THE BRAINSTEM AND HYPOTHALAMUS}

The hypothalamus is often regarded as the "gate keeper" of appetite signalling as it also receives input from the cortex, brain stem and the periphery (Figures 1 and $2)$. Similarly to the ARC, the area postrema of the brain stem also possesses an incomplete blood brain barrier. As such, peripheral satiety signals can also act directly on brainstem structures. Extensive reciprocal neuronal pathways exist between brainstem and hypothalamic appetite circuits to provide an alternative pathway through which circulating satiety factors can communicate with the hypothalamus $(48,49)$. An additional major link between the gastrointestinal tract and the brain exists via the vagus nerve. Cell bodies of afferent fibers of the abdominal vagus nerve are located in the nodose ganglia, which project onto the brainstem. Here, the dorsal vagal complex (DVC) (consisting of the dorsal motor nucleus, the area postrema, and the sensory nucleus of the tractus solitarius (NTS)) contains projections to hypothalamic and higher centers $(48,49)$.

\section{GUT HORMONES}

The gastrointestinal tract releases an array of peptide hormones that are sensitive to gut nutrient content. Furthermore, short-term feelings of hunger and satiety are believed to be partly mediated by co-ordinated changes in circulating gut hormone concentrations.

\section{Cholecystokinin (CCK)}

CCK was the first gut hormone demonstrated to have an effect on food intake. CCK is released post-prandially and in addition to local effects within the gut, inhibits food intake in rodents and humans $(50,51)$. CCKl receptor knockout rats and intraperitoneal delivery of CCKI antagonists results in obesity, partly due to hyperphagia (52). The anorectic effects of peripherally administered CCK are thought to be mediated via CCK 1 receptors on vagal afferent fibres that relay to the brainstem. Interestingly, intraperitoneal CCK administration also increases $c$-fos expression in the DMN and PVN of the hypothalamus (53). Direct administration of CCK into the DMN decreases food intake and down-regulates NPY gene expression (53).

\section{Glucagon like peptide-1 (GLP-1)}

The pre-pro-glucagon gene is widely expressed in the enteroendocrine L cells of the intestine, pancreas and brainstem. It is cleaved by pro-hormone convertases 1 and 2 to produce mainly glucagon in the pancreas, and GLP-1, GLP-2 and oxyntomodulin in the CNS and intestine. GLP-1 is released into the circulation following a meal in proportion to the calories consumed and acts via the vagus nerve to inhibit food intake (54). Central administration of GLP-1 to rats inhibits food intake and activates $c$-fos expression in the ARC, amygdala and PVN $(54,55)$. GLP-1 receptor mRNA is densely expressed in the ARC and over 60\% appears to be co-localized with POMC neurons (56). Peripherally injected GLP- 1 also induces expression of $c$-fos in the ARC and has an anorectic effect (57). However, this is thought to be mediated, in part, via the vagus nerve since vagotomy or ablation of the brainstem-hypothalamus pathways attenuates the anorectic effect of GLP-1 (57).

\section{Oxyntomodulin}

Like GLP-1, oxyntomodulin is secreted from intestinal $\mathrm{L}$ cells post-prandially and reduces food intake when administered peripherally or ICV to rodents (58). Peripheral administration of oxyntomodulin activates $c$-fos expression in the ARC and its anorectic effects can be blocked through the use of a GLP-1 antagonist (58). As a member of the secretin glucagon family of peptides, oxyntomodulin differs in producing a stronger inhibition of food intake than other members and has an anorectic action disproportionate to its binding to the GLP-1 receptor suggesting the possibility of an additional mode of action.

\section{Ghrelin}

Ghrelin is produced by the stomach and acts as an endogenous ligand on the growth hormone secretagogue (GHS) receptor. Although the majority of ghrelin is produced peripherally, there are ghrelin immunoreactive neurons within the hypothalamus that have terminals on hypothalamic NPY/AgRP, POMC and CRH 
neurons (59), as well as orexin fibres in the LHA (60). Ghrelin initiates hunger prior to a meal and stimulates food intake when injected directly into the PVN (61). Peripheral and central administration of ghrelin increases $c$-fos expression in ARC NPY/AgRP neurons and increases hypothalamic NPY mRNA expression (62). Although, ghrelin has potent actions on appetite, ghrelin null mice have normal appetite and body weight when fed a standard diet however do resist diet-induced obesity (63). This may be due to up-regulation of alternative systems controlling appetite or perhaps ghrelin has only short term effects on food intake, playing a smaller role in the overall regulation of appetite.

\section{Peptide YY (PYY)}

$\mathrm{PYY}_{3-36}$ is a member of the PP-fold family of peptides released by L-cells in the gut, into the circulation following a meal. The PP-fold family comprises NPY, PYY and pancreatic polypeptide (PP) although $\mathrm{PYY}_{3-36}$ is relatively selective for the $\mathrm{Y} 2$ receptor. Peripheral administration of $\mathrm{PYY}_{3-36}$ reduces food intake in rodents and humans and PY knockout mice develop obesity $(64,65)$. Although the exact mechanisms are unclear, the anorectic effects of $\mathrm{PYY}_{3-36}$ are thought to occur via the Y2 receptor since this is abolished in $\mathrm{Y} 2$ receptor knockout mice (64). The Y2 receptor is highly expressed on ARC NPY neurons and $\mathrm{PYY}_{3-36}$ may reduce food intake by inhibiting NPY release via autoinhibitory Y2 receptors. Interestingly vagotomy or lesioning of the brainstemhypothalamic neuronal pathways abolishes the anorectic effects of peripheral $\mathrm{PYY}_{3-36}(57)$. This observation, combined with evidence for Y2 receptor expression in the NTS and nodose ganglion of the vagus nerve, has led to the proposal that PYY ${ }_{3-36}$ may regulate ARC neuronal activity indirectly via vagal-brainstem pathways.

\section{Pancreatic polypeptide (PP)}

The anorectic gut hormone PP is released from the pancreas into the circulation after a meal and like PYY, is released in proportion to calories ingested. Peripheral injection of PP to rodents and humans reduces food intake $(66,67)$. Peripheral PP administration activates neurons in the area postrema of the brainstem, an area with a high density of Y4 receptors and reduces hypothalamic NPY and orexin mRNA expression (66). Like PYY, the reduction of food intake by intraperitoneal PP is abolished by vagotomy in rodents (66).

\section{NUTRIENT SENSING}

There is evidence that the hypothalamus can also sense nutrients and adjust food intake accordingly. When cellular energy stores are deplete, the enzyme adenosine monophosphate-activated protein kinase (AMPK) is activated in order to increase substrate uptake (68). In the ARC, activation of AMPK leads to increased food intake and body weight; an effect which is inhibited by both insulin and leptin (69). AMPK in the VMN also appears to play a key role in the detection of acute hypoglycaemia and initiation of the glucose counter-regulatory response (70). Acute hypoglycaemia also increases hypothalamic NPY and AgRP and reduces POMC expression (71). Other nutrients such as plasma long chain fatty acids and the amino acid leucine can regulate food intake via the hypothalamus. ICV administration of the long chain fatty acid, oleic acid inhibits food intake by reduction of ARC AgRP and NPY expression (72) and ICV administration of leucine reduces food intake in rats $(73)$.

\section{REWARD MECHANISMS AND HYPOTHALAMIC APPETITE REGULATION}

Reward mechanisms are thought to predominantly involve the mesolimbic system in the brain. Conditioned Taste Aversion (CTA) and lesioning experiments suggest the orbitofrontal cortex and amygdala are important in learning and experiencing food and its subsequent effect on food intake. MCH and orexin fibres in the LHA transmit and receive information from the cerebral cortex (28). In addition, the LHA receives an inhibitory input from the shell of the nucleus accumbens which in turn receives inputs from the prefrontal cortex (74).

Reward pathways utilise dopamine, opioids, serotonin and noradrenaline neuronal fibres which connect the hindbrain and midbrain to the hypothalamus and all are known to affect appetite when injected into hypothalamic nuclei. In addition, orexigenic NPY and anorexigenic POMC neurons in the ARC have projections throughout the brain including the serotonergic system in the raphe nuclei and areas involved in reward such as the amygdala.

There has been significant research looking at the role of endocannabinoids in appetite. Evidence to date suggests that endocannabinoids act as orexigenic signals via cannabinoid CBI receptors in the CNS (75). $\mathrm{CB} 1$ receptors are expressed in key hypothalamic areas regulating appetite such as the PVN (75). Blocking 
CBI receptors inhibits food intake and causes weight loss in rodents (76). The weight-reducing effect of $\mathrm{CBl}$ antagonists (e.g. rimonabant) has been used in the treatment of human obesity until recently.

\section{CLINICAL THERAPEUTIC APPLICATIONS}

The hypothalamic control of appetite is complex and relies not just on signalling pathways within the brain but also peripheral signals acting via the brainstem and reward circuitries. As such, there are multiple potential targets for developing anti-obesity agents. At present only two drugs are licensed by the Food and Drug Administration for long term therapy against obesity: orlistat and sibutramine. Orlistat is an inhibitor of pancreatic and gastrointestinal lipases preventing the absorption of dietary fat. The gastrointestinal side effects of diarrhoea and oily stools reduces compliance. Interestingly, a recent study has shown reduced plasma levels of CCK, PYY and GLP-1 following orlistat treatment in humans (77). Sibutramine is a serotonin and noradrenaline reuptake inhibitor and is contra-indicated in patients with hypertension. Both drugs result in very modest weight loss in clinical trials, perhaps between $4 \%-8 \%$. Work is currently underway to identify novel treatments that act within the CNS to control appetite. MC4 receptor agonists (78) and drugs that modulate NPY (79) and serotonergic (80) signalling are currently being investigated however they have the disadvantage of affecting more functions than just appetite. Further, due to the complexity of neuronal circuits involved in appetite control, it is unlikely that targeting one specific pathway will result in prolonged and clinically relevant weight loss. The ability to modulate central pathways using peripherally administered physiological appetite regulating agents is more likely to be a successful, low side effect, approach. If we can mimic the success of bypass surgery by administering the responsible gut hormones we may be able to provide real hope for effective treatments for obese patients.

Disclosure: No potential conflict of interest relevant to this article was reported.

\section{REFERENCES}

1. World Health Organisation. Genomics and World Health, Report of the Advisory Committee on Health Research - Summary. 2002.

2. Must A, Spadano J, Coakley EH, Field AE, Colditz G, Dietz WH. The disease burden associated with overweight and obesity. JAMA. 1999;282(16):1523-9.
3. Miller J, Rosenbloom A, Silverstein J. Childhood obesity. J Clin Endocrinol Metab. 2004;89(9):4211-8.

4. Olney JW. Brain lesions, obesity, and other disturbances in mice treated with monosodium glutamate. Science. 1969;164(880):719-21.

5. Bouret SG, Draper SJ, Simerly RB. Formation of projection pathways from the arcuate nucleus of the hypothalamus to hypothalamic regions implicated in the neural control of feeding behavior in mice. J Neurosci. 2004;24(11):2797-805.

6. Kishi T, Aschkenasi CJ, Lee CE, Mountjoy KG, Saper CB, Elmquist JK. Expression of melanocortin 4 receptor mRNA in the central nervous system of the rat. J Comp Neurol. 2003;457(3):213-35.

7. Huszar D, Lynch CA, Fairchild-Huntress V, Dunmore JH, Fang $Q$, Berkemeier LR, et al. Targeted disruption of the melanocortin-4 receptor results in obesity in mice. Cell. 1997;88(1):131-41.

8. Chen AS, Marsh DJ, Trumbauer ME, Frazier EG, Guan XM, Yu H, et al. Inactivation of the mouse melanocortin-3 receptor results in increased fat mass and reduced lean body mass. Nat Genet. 2000;26(1):97-102.

9. Cone RD. Studies on the physiological functions of the melanocortin system. Endocr Rev. 2006;27(7):736-49.

10. Yaswen L, Diehl N, Brennan MB, Hochgeschwender U. Obesity in the mouse model of pro-opiomelanocortin deficiency responds to peripheral melanocortin. Nat Med. 1999;5(9):1066-70.

11. Bagnol D, Lu XY, Kaelin CB, Day HE, Ollmann M, Gantz I, et al. Anatomy of an endogenous antagonist: relationship between Agouti-related protein and proopiomelanocortin in brain. J Neurosci. 1999;19(18):RC26.

12. Faroogi IS, Keogh JM, Yeo GS, Lank EJ, Cheetham T, O'Rahilly S. Clinical spectrum of obesity and mutations in the melanocortin 4 receptor gene. N Engl J Med. 2003;348(12):1085-95.

13. Krude H, Biebermann H, Luck W, Horn R, Brabant G, Gruters A. Severe early-onset obesity, adrenal insufficiency and red hair pigmentation caused by POMC mutations in humans. Nat Genet. 1998;19(2):155-7.

14. Kristensen $P$, Judge ME, Thim L, Ribel U, Christjansen KN, Wulff $\mathrm{BS}$, et al. Hypothalamic CART is a new anorectic peptide regulated by leptin. Nature. 1998;393(6680):72-6.

15. Aja S, Sahandy S, Ladenheim EE, Schwartz GJ, Moran TH. Intracerebroventricular CART peptide reduces food intake and alters motor behavior at a hindbrain site. Am J Physiol Regul Integr Comp Physiol. 2001;281(6):R1862-R1867.

16. Asnicar MA, Smith DP, Yang DD, Heiman ML, Fox N, Chen YF, et al. Absence of cocaine- and amphetamine-regulated transcript results in obesity in mice fed a high caloric diet. Endocrinology. 2001;142(10):4394-400.

17. Abbott CR, Rossi M, Wren AM, Murphy KG, Kennedy AR, Stanley $S A$, et al. Evidence of an orexigenic role for cocaine- and amphetamine-regulated transcript after administration into discrete hypothalamic nuclei. Endocrinology. 2001;142(8):3457-63.

18. Kong WM, Stanley S, Gardiner J, Abbott C, Murphy K, Seth A, et al. A role for arcuate cocaine and amphetamine-regulated transcript in hyperphagia, thermogenesis, and cold adaptation. FASEB J. 2003;17(12):1688-90.

19. Broberger $C$, Johansen J, Johansson $C$, Schalling M, Hokfelt T. The neuropeptide Y/agouti gene-related protein (AGRP) brain circuitry in normal, anorectic, and monosodium glutamate-treated mice. Proc Natl Acad Sci USA. 1998;95(25):15043-8.

20. Bewick GA, Gardiner JV, Dhillo WS, Kent AS, White NE, Webster $Z$, et al. Post-embryonic ablation of AgRP neurons in mice leads to a lean, hypophagic phenotype. FASEB J. 2005;19(12):1680-2.

21. Clark JT, Kalra PS, Crowley WR, Kalra SP. Neuropeptide $Y$ and human pancreatic polypeptide stimulate feeding behavior in rats. Endocrinology. 1984;115(1):427-9. 
22. Baker RA, Herkenham M. Arcuate nucleus neurons that project to the hypothalamic paraventricular nucleus: neuropeptidergic identity and consequences of adrenalectomy on mRNA levels in the rat. J Comp Neurol. 1995;358(4):518-30.

23. Kim MS, Rossi M, Abusnana S, Sunter D, Morgan DG, Small CJ, et al. Hypothalamic localization of the feeding effect of agoutirelated peptide and alpha-melanocyte-stimulating hormone. Diabetes. 2000;49(2):177-82

24. Stanley BG, Chin AS, Leibowitz SF. Feeding and drinking elicited by central injection of neuropeptide $Y$ : evidence for a hypothalamic site(s) of action. Brain Res Bull. 1985;14(6):521-4.

25. Legradi G, Lechan RM. Agouti-related protein containing nerve terminals innervate thyrotropin-releasing hormone neurons in the hypothalamic paraventricular nucleus. Endocrinology. 1999;140(8):3643-52.

26. Martin NM, Smith KL, Bloom SR, Small CJ. Interactions between the melanocortin system and the hypothalamo-pituitary-thyroid axis. Peptides. 2006;27(2):333-9.

27. Broberger C, De LL, Sutcliffe JG, Hokfelt T. Hypocretin/orexinand melanin-concentrating hormone-expressing cells form distinct populations in the rodent lateral hypothalamus: relationship to the neuropeptide $Y$ and agouti gene-related protein systems. J Comp Neurol. 1998;402(4):460-74.

28. Bittencourt JC, Presse F, Arias C, Peto C, Vaughan J, Nahon JL, et al. The melanin-concentrating hormone system of the rat brain: an immuno- and hybridization histochemical characterization. J Comp Neurol. 1992;319(2):218-45.

29. Chen Y, Hu C, Hsu CK, Zhang Q, Bi C, Asnicar M, et al. Targeted disruption of the melanin-concentrating hormone receptor-1 results in hyperphagia and resistance to diet-induced obesity. Endocrinology. 2003;143(7):2469-77.

30. Qu D, Ludwig DS, Gammeltoft S, Piper M, Pelleymounter $\mathrm{MA}$, Cullen $\mathrm{MJ}$, et al. A role for melanin-concentrating hormone in the central regulation of feeding behaviour. Nature. 1996;380(6571):243-7.

31. Sakurai T, Amemiya A, Ishii M, Matsuzaki I, Chemelli RM, Tanaka $H$, et al. Orexins and orexin receptors: a family of hypothalamic neuropeptides and $\mathrm{G}$ protein-coupled receptors that regulate feeding behavior. Cell. 1998;92(4):573-85.

32. Hagan JJ, Leslie RA, Patel S, Evans ML, Wattam TA, Holmes S, et al. Orexin A activates locus coeruleus cell firing and increases arousal in the rat. Proc Natl Acad Sci USA. 1999;96(19):10911-6.

33. Bernardis LL, Bellinger LL. The dorsomedial hypothalamic nucleus revisited: 1986 update. Brain Res. 1987;434(3):321-81.

34. Jacobowitz DM, O'DonohueTL. Alpha-melanocyte stimulating hormone: immunohistochemical identification and mapping in neurons of rat brain. Proc Natl Acad. Sci USA. 1978;75(12):6300-4.

35. Mihaly E, Fekete C, Legradi G, Lechan RM. Hypothalamic dorsomedial nucleus neurons innervate thyrotropin-releasing hormone-synthesizing neurons in the paraventricular nucleus. Brain Res. 2001;891(1-):20-31.

36. Guan XM, Yu H, Trumbauer M, Frazier E, Van der Ploeg LH, Chen $\mathrm{H}$. Induction of neuropeptide $\mathrm{Y}$ expression in dorsomedial hypothalamus of diet-induced obese mice. Neuroreport. 1998;9(15):3415-9.

37. Kesterson RA, Huszar D, Lynch CA, Simerly RB, Cone RD. Induction of neuropeptide $Y$ gene expression in the dorsal medial hypothalamic nucleus in two models of the agouti obesity syndrome. Mol Endocrinol. 1997;11(5):630-7.

38. Matsuda M, Liu Y, Mahankali S, PuY, Mahankali A, Wang J, et al. Altered hypothalamic function in response to glucose ingestion in obese humans. Diabetes. 1999;48(9):1801-6.

39. Pelleymounter MA, Cullen MJ, Wellman CL. Characteristics of BDNF-induced weight loss. Exp Neurol. 1995;131(2):229-38.
40. Xu B, Goulding EH, Zang K, Cepoi D, Cone RD, Jones KR, et al. Brain-derived neurotrophic factor regulates energy balance downstream of melanocortin-4 receptor. Nat Neurosci. 2003;6(7):736-42.

41. Ahima RS, Lazar MA. Adipokines and the peripheral and neural control of energy balance. Mol Endocrinol. 2008;22(5):1023-31.

42. Farooqi IS, Jebb SA, Langmack G, Lawrence E, Cheetham CH, Prentice AM, et al. Effects of recombinant leptin therapy in a child with congenital leptin deficiency. N Engl J Med. 1999;341(12):879-84.

43. Faouzi M, Leshan R, Bjornholm M, Hennessey T, Jones J, Munzberg $\mathrm{H}$. Differential accessibility of circulating leptin to individual hypothalamic sites. Endocrinology. 2007;148(11):5414-23.

44. Bagnasco M, Dube MG, Kalra PS, Kalra SP. Evidence for the existence of distinct central appetite, energy expenditure, and ghrelin stimulation pathways as revealed by hypothalamic site-specific leptin gene therapy. Endocrinology. 2002;143(11):4409-21.

45. Cowley MA, Smart JL, Rubinstein M, Cerdan MG, Diano S, Horvath $\mathrm{TL}$, et al. Leptin activates anorexigenic $\mathrm{POMC}$ neurons through a neural network in the arcuate nucleus. Nature. 2001;411(6836):480-4.

46. McGowan MK, Andrews KM, Grossman SP. Chronic intrahypothalamic infusions of insulin or insulin antibodies alter body weight and food intake in the rat. Physiol Behav. 1992;51(4):753-66.

47. Benoit SC, Air EL, Coolen LM, Strauss R, Jackman A, Clegg DJ, et al. The catabolic action of insulin in the brain is mediated by melanocortins. J Neurosci. 2002;22(20):9048-52.

48. ter Horst GJ, Luiten PG, Kuipers F. Descending pathways from hypothalamus to dorsal motor vagus and ambiguus nuclei in the rat. J Auton Nerv Syst. 1984;11(1):59-75.

49. ter Horst GJ, de BP, Luiten PG, van Willigen JD. Ascending projections from the solitary tract nucleus to the hypothalamus. A Phaseolus vulgaris lectin tracing study in the rat. Neuroscience. 1989:31(3):785-97.

50. Gibbs J, Young RC, Smith GP. Cholecystokinin decreases food intake in rats. J Comp Physiol Psychol. 1973 84(3):488-95.

51. Kissileff HR, Pi-Sunyer FX, Thornton J, Smith GP. C-terminal octapeptide of cholecystokinin decreases food intake in man. Am J Clin Nutr. 1981;34(2):154-60.

52. Silver AJ, Flood JF, Song AM, Morley JE. Evidence for a physiological role for CCK in the regulation of food intake in mice. Am J Physiol. 1989;256(3 Pt 2):R646-R652.

53. Chen J, Scott KA, Zhao Z, MoranTH, Bi S. Characterization of the feeding inhibition and neural activation produced by dorsomedial hypothalamic cholecystokinin administration. Neuroscience. 2008;152(1):178-88.

54. Turton MD, O'Shea D, Gunn I, Beak SA, Edwards CM, Meeran K, et al. A role for glucagon-like peptide- 1 in the central regulation of feeding. Nature. 1996;379(6560):69-72.

55. Larsen PJ, Tang-Christensen M, Jessop DS. Central administration of glucagon-like peptide-1 activates hypothalamic neuroendocrine neurons in the rat. Endocrinology. 1997;138(10):4445-55.

56. Sandoval DA, Bagnol D, Woods SC, D'Alessio DA, Seeley RJ. Arcuate GLP-1 receptors regulate glucose homeostasis but not food intake. Diabetes. 2008;57(8):2046-54.

57. Abbott CR, Monteiro M, Small CJ, Sajedi A, Smith KL, Parkinson $J R$, et al. The inhibitory effects of peripheral administration of peptide $Y Y(3-36)$ and glucagon-like peptide-1 on food intake are attenuated by ablation of the vagal-brainstem-hypothalamic pathway. Brain Res. 2005;1044(1):127-31.

58. Dakin CL, Small CJ, Batterham RL, Neary NM, Cohen MA, Patterson $\mathrm{M}$, et al. Peripheral oxyntomodulin reduces food intake and body weight gain in rats. Endocrinology. 2004;145(6):2687-95.

59. Cowley MA, Smith RG, Diano S, Tschop M, Pronchuk N, Grove $\mathrm{KL}$, et al. The distribution and mechanism of action of ghrelin in the CNS demonstrates a novel hypothalamic circuit regulating energy homeostasis. Neuron. 2003;37(4):649-61. 
60. Toshinai K, Date Y, Murakami N, Shimada M, Mondal MS, Shimbara T, et al. Ghrelin-induced food intake is mediated via the orexin pathway. Endocrinology. 2003;144(4):1506-12.

61. Shrestha YB, Wickwire K, Giraudo SQ. Action of MT-II on ghrelininduced feeding in the paraventricular nucleus of the hypothalamus. Neuroreport. 2004;15(8):1365-7.

62. Nakazato M, Murakami N, DateY, Kojima M, Matsuo H, Kangawa $\mathrm{K}$, et al. A role for ghrelin in the central regulation of feeding. Nature. 2004;409(6817):194-8.

63. Sun Y, Ahmed S, Smith RG. Deletion of ghrelin impairs neither growth nor appetite. Mol Cell Biol. 2003;23(22):7973-81.

64. Batterham RL, Cowley MA, Small CJ, Herzog H, Cohen MA, Dakin $\mathrm{CL}$, et al. Gut hormone PYY(3-36) physiologically inhibits food intake. Nature. 2002;418(6898):650-4.

65. Boey D, Lin S, Karl T, Baldock P, Lee N, Enriquez R, et al. Peptide $Y Y$ ablation in mice leads to the development of hyperinsulinaemia and obesity. Diabetologia. 2006;49(6):1360-70.

66. Asakawa A, Inui A, Yuzuriha H, Ueno N, Katsuura G, Fujimiya M, et al. Characterization of the effects of pancreatic polypeptide in the regulation of energy balance. Gastroenterology. 2003;124(5):1325-36.

67. Batterham RL, Le Roux CW, Cohen MA, Park AJ, Ellis SM, Patterson $\mathrm{M}$, et al. Pancreatic polypeptide reduces appetite and food intake in humans. J Clin Endocrinol Metab. 2003;88(8):3989-92.

68. Hardie DG. The AMP-activated protein kinase pathway-new players upstream and downstream. J Cell Sci. 2004;117(Pt 23):5479-87.

69. MinokoshiY, AlquierT, Furukawa N, Kim YB, Lee A, Xue B, et al. AMPkinase regulates food intake by responding to hormonal and nutrient signals in the hypothalamus. Nature. 2004;428(6982):569-74.

70. McCrimmon RJ, Shaw M, Fan X, Cheng H, Ding Y, Vella MC, et al. Key role for AMP-activated protein kinase in the ventromedial hypothalamus in regulating counterregulatory hormone responses to acute hypoglycemia. Diabetes. 2008;57(2):444-50.
71. Ritter S, Dinh TT, Li AJ. Hindbrain catecholamine neurons control multiple glucoregulatory responses. Physiol Behav. 2006;89(4):490-500.

72. Morgan K, Obici S, Rossetti L. Hypothalamic responses to long-chain fatty acids are nutritionally regulated. J Biol Chem. 2004;279(30):31139-48.

73. Cota D, Proulx K, Smith KA, Kozma SC, Thomas G, Woods SC, et al. Hypothalamic mTOR signaling regulates food intake. Science. 2006;312(5775):927-30.

74. Kelley AE. Ventral striatal control of appetitive motivation: role in ingestive behavior and reward-related learning. Neurosci Biobehav Rev. 2004;27(8):765-76.

75. Pagotto U, Marsicano G, Cota D, Lutz B, Pasquali R. The emerging role of the endocannabinoid system in endocrine regulation and energy balance. Endocr Rev. 2006;27(1):73-100.

76. Osei-Hyiaman D, Depetrillo M, Harvey-White J, Bannon AW, Cravatt BF, Kuhar MJ, et al. Cocaine- and amphetamine-related transcript is involved in the orexigenic effect of endogenous anandamide. Neuroendocrinology. 2005;81(4):273-82.

77. Ellrichman M, Kapelle M, Ritter PR, Holst JJ, Herzig KH, Schmidt WE, et al. Orlistat inhibition of intestinal lipase acutely increases appetite and attenuates postprandial glucagon-like peptide-1-(736)-amide-1, cholecystokinin, and peptide YY concentrations. J Clin Endocrinol Metab. 2008;93(10):3995-8.

78. Wikberg JE, Mutulis F. Targeting melanocortin receptors: an approach to treat weight disorders and sexual dysfunction. Nat Rev Drug Discov. 2008;7(4):307-23.

79. Kamiji MM, Inui A. Neuropeptide $Y$ receptor selective ligands in the treatment of obesity. Endocr Rev. 2007;28(6):664-84.

80. Halford JC, Harrold JA, Lawton CL, Blundell JE. Serotonin (5-HT) drugs: effects on appetite expression and use for the treatment of obesity. Curr Drug Targets. 2005;6(2):201-13. 